\title{
How can energy prices and subsidies accelerate the integration of electric vehicles in Brazil? An economic analysis
}

\author{
Ricardo Emilio da Silva ${ }^{\mathrm{a}, *}$, Pedro Magalhães Sobrinho ${ }^{\mathrm{a}}$, Teófilo Miguel de Souza ${ }^{\mathrm{b}}$ \\ a UNESP-Sao Paulo State University, Department of Energy, Av. Dr. Ariberto Pereira da Cunha, 333, Guaratinguetá, SP, 12.516-410, Brazil \\ b UNESP-Sao Paulo State University, Department of Electrical Engineering, Av. Dr. Ariberto Pereira da Cunha, 333, Guaratinguetá, SP, 12.516-410, Brazil
}

\section{A R T I C L E I N F O}

\section{Keywords:}

Battery electric vehicles

Brazil

Energy planning

Energy prices

Incentives

\begin{abstract}
A B S T R A C T
A sensitivity analysis indicates that the variables that most influence the payback period on purchases of battery electric vehicles are gasoline prices and financial incentives granted in the form of an exemption from the annual tax payment. Currently, the arithmetic mean value of the payback period for the purchase of BEVs is 24.23 years in 27 analyzed state capitals, suggesting broad-based adoption remains years away.
\end{abstract}

\section{Introduction}

The use of fossil fuels in conventional vehicles, which are those which convert liquid fuels energy, such as diesel and gasoline, into mechanical energy by means of an internal combustion engine (ICE), has increased greenhouse gases (GHG) emissions and other pollutants into the atmosphere, most critically carbon dioxide $\left(\mathrm{CO}_{2}\right)$, where the observed increase in its concentration in the atmosphere has risen $40 \%$ from $280 \mathrm{ppm}$ in the pre-industrial revolution period to $391 \mathrm{ppm}$ by the year 2011, with an average growth rate of $2.0 \pm 0.1 \mathrm{ppm}$ per year within the period of 2002 and 2011 (IPCC, 2014). As regards annual GHG emissions worldwide, the increase was from $27 \mathrm{Gt} \mathrm{CO}_{2} \mathrm{eq} /$ year to $49 \mathrm{Gt} \mathrm{CO}_{2}$ eq/year between 1970 and 2010, which corresponds to an increase of approximately $81 \%$, where the transportation sector emissions were accountable for $14 \%$ of total GHG emissions in 2010 , with approximately $6.9 \mathrm{Gt} \mathrm{CO}_{2} \mathrm{eq} /$ year (IPCC, 2014).

In Brazil, total GHG emissions were $1.2 \mathrm{Gt} \mathrm{CO}_{2} \mathrm{eq}$ in 2012, with the transportation sector being accountable for $16.7 \%$ of such emissions, which corresponds to $0.2 \mathrm{Gt} \mathrm{CO}_{2} \mathrm{eq} /$ year. If only the road transportation sector was taken into account, emissions would have been $0.18 \mathrm{Gt}$ $\mathrm{CO}_{2}$ eq in 2012 , or $15 \%$ of the country's total emissions (MCTI, 2014). In view of the significant contribution of the transportation sector to such emissions, transportation modes that reduce GHG emissions and air pollutants merit serious study, particularly electric vehicle (EV) technology.

The term electric vehicle encompasses hybrid electric vehicles (HEV) and plug-in electric vehicles (PEV). HEVs use an internal combustion engine and batteries that are recharged as part of normal operation of the vehicle; they cannot be recharged by the electricity network. PEVs can be plug-in hybrid electric vehicles (PHEV) or battery electric vehicles (BEV). PHEVs can have both electric and internal combustion engines, while BEVs only have electricity-driven engines (Bonges and Lusk et al., 2016). In the case of PHEVs, the ICE is used when the battery is being partially used, especially under conditions of sudden acceleration. Extended-range electric vehicles (EREV) are a special type of PHEVs with a high-capacity battery that is able to power the vehicle until it is fully dead, point at which the vehicle switches to ICE operation mode. Therefore, PHEVs run on gasoline during the period of battery discharge, while EREVs do not (Noori et al., 2015). Both BEVs and PHEVs (including EREVs) can be recharged by the electricity network.

Examples of HEVs are the Toyota Prius, Ford Fusion Hybrid, and Lexus CT. Examples of PHEVs are the Chevrolet Volt, Ford Fusion Energi, and Mitsubishi Outlander PHEV, with the Chevrolet Volt considered an EREV. The Nissan Leaf, Tesla Model S, BMW i3, Renault Zoe, and Kia Soul EV are examples of BEVs.

While Brazil is the eighth-largest vehicle manufacturer and the fourth-largest consuming market in the world, only 843 new electric and hybrid cars were licensed in the year 2015, representing only $0.04 \%$ of the total of licensed cars in the country (ANFAVEA, 2016). This shows that the necessary conditions for integrating electric vehicles in the country have not been created yet, and that there is still room to develop policies to support the proliferation of such vehicles into the Brazilian market, as has occurred in other countries. In 2014, electric vehicles sale accounted for over 300,000 units worldwide, dominated by the United States (over 100,000 units), China (over

\footnotetext{
* Corresponding author. Present address: Av. Sarah Kubitschek, 260, apt 03, Cachoeira Paulista, SP, 12.630-000, Brazil.

E-mail addresses: ricardo.emilio@inpe.br (R.E. da Silva), sobrinho@feg.unesp.br (P.M. Sobrinho), teofilo@feg.unesp.br (T.M. de Souza).
} 
50,000 units), Japan (over 30,000 units) and Norway (around 20,000 units) (ICCT, 2015).

Several studies on electric vehicles have been conducted in Brazil and around the world. Silvia and Krause (2016) analyzed the impact that different political interventions could have on the adoption of battery electric vehicles in urban regions of the United States, and concluded that, although the replacement of conventional gasoline vehicles for electric vehicles brings public benefits, including the reduction of urban pollution and GHG emissions and increased energy security, it offers no private equivalent benefits.

Research conducted by Rusich and Danielis (2015) has estimated the total cost of ownership (TCO) and energy consumption during the life cycle of different automotive technologies available in Italy in 2013, and found that conventional vehicles have the lowest total cost of ownership, while battery electric vehicles feature better energy efficiency in the context of the Italian electricity generation matrix. It was also observed that battery electric vehicles are economically attractive to consumers when the annual distance traveled by the vehicle is at least $20,000 \mathrm{~km}$, a much greater distance than the average in Italy, and that battery electric vehicles would only be economically competitive within the current average annual distance traveled by Italian vehicles if subsidies were granted and battery prices reduced by $42 \%$.

Working off official estimates in Brazil, Baran and Legey (2013) believe the use of electric vehicles could reduce gasoline consumption by up to $40.7 \%$ by the year 2030 , and increase electricity consumption in $31.3 \%$, representing a $28.9 \%$ decrease in total energy consumption by the national fleet, or about $24.6 \times 10^{6}$ toe/year.

Dias et al. (2014) assessed the impact on electricity demand and emissions as a result of electric vehicles introduction in the State of Sao Paulo by using the simulation tool "Long range Energy Alternatives Planning System" (LEAP). In energy terms, it has been found that, if the state government in São Paulo compulsorily stipulated that $100 \%$ of the car fleet must be made up of electric vehicles by the year 2035, there would be a 40 TWh increase in electricity consumption compared to the status quo while, environmentally, such an initiative would reduce $\mathrm{CO}_{2}$ eq emissions in $\mathbf{1 7 . 3}$ million tons.

Nevertheless, it should be observed that neither the aforementioned items of research nor others available in the literature carry out an indepth economic analysis from the consumers' perspective, i.e. how far each Brazilian city is from integration of EVs in its road matrix, since consumers would only be attracted to purchasing EVs if these were economically viable. There is great variation in prices of electricity, gasoline, and annual taxes among the capitals of each Brazilian state, so that an individual analysis of economic aspects of each city is vital to implementing effective public policies.

Therefore, the aim of this work is to present an overview of the economic aspects of BEV purchases from the consumers' perspective in all Brazilian state capitals in order to fill in a gap in the literature, so that decision-makers can have subsidies and hard data to plan the integration of electric vehicles in the country.

\section{Methodology}

\subsection{Economic analysis}

The economic viability analysis of purchasing battery electric vehicles is performed by calculating the payback period for each Brazilian capital. The following equation is used to calculate the payback period of purchasing a battery electric vehicle:

$P B=\frac{C I}{R}$

where PB is the payback period [years], CI is the cost of investment in $\mathrm{BEVs}$ [US\$] and $\mathrm{R}$ is the annual revenue generated from BEVs [US $\$$ /year].

For the mathematical development (1), the following equations are used:

$R=A D T \cdot\left(C_{I C E V}-C_{B E V}\right)+\left(T_{I C E V}-(1-D) \cdot T_{B E V}\right)$

$C_{I C E V}=\frac{P_{g a s}}{F E_{I C E V}}$

$C_{B E V}=\frac{W_{\text {bat. } B E V} \cdot P_{\text {elec }}}{T R_{B E V}}$

$T R_{B E V}=W_{b a t . B E V} \cdot F E_{B E V}$

where ADT is the annual distance traveled [km/year], $\mathrm{C}_{\mathrm{ICEV}}$ is the specific cost of using conventional vehicles by distance traveled [US $\$ / \mathrm{km}], \mathrm{C}_{\mathrm{BEV}}$ is the specific cost of using battery electric vehicles by distance traveled [US\$ $/ \mathrm{km}$ ], $\mathrm{T}_{\mathrm{ICEV}}$ is the annual tax of conventional vehicles [US\$/year], D is the discount percentage on annual tax payment granted to battery electric vehicles [\%], $\mathrm{T}_{\mathrm{BEV}}$ is the annual tax of battery electric vehicles [US\$/year], $\mathrm{P}_{\text {gas }}$ is the price of gasoline [US $\$ / 1], \mathrm{FE}_{\mathrm{ICEV}}$ is the fuel economy of conventional vehicles run on gasoline $[\mathrm{km} / \mathrm{l}], \mathrm{W}_{\text {bat.BEv }}$ is the amount of electricity required to recharge the batteries of electric vehicles $[\mathrm{kWh}], \mathrm{P}_{\text {elec }}$ is the price of electricity [US\$/kWh], TR $\mathrm{BEV}_{\mathrm{BEV}}$ is the total range of electric vehicles $[\mathrm{km}]$ and $\mathrm{FE}_{\mathrm{BEV}}$ is the fuel economy of battery electric vehicles $[\mathrm{km} / \mathrm{kWh}]$.

By using (2)-(5), the payback period of battery electric vehicles can be rewritten as follows:

$P B=\frac{C I \cdot F E_{I C E V}}{A D T \cdot\left(P_{\text {gas }}-\frac{F E_{I C E V}}{F E_{B E V}} \cdot P_{\text {elec }}\right)+F E_{I C E V} \cdot\left(T_{I C E V}-(1-D) \cdot T_{B E V}\right)}$

\subsection{Data}

The residential electricity and gasoline prices, annual taxes of conventional and battery electric vehicles, as well as the discount percentage on annual tax payment that is granted to BEVs used in this study are shown in Table 1.

The assumptions related to the data on vehicles and their intensity of use are shown in Table 2.

\section{Results and discussion}

\subsection{Evolution of energy prices}

Energy prices directly affect the economic viability of purchasing electric and hybrid vehicles in such a way that a detailed analysis of the evolution of electricity and gasoline prices becomes important to identify the behavior of past prices and estimate future prices of such products.

In Brazil, electricity prices are set by its National Electricity Regulatory Agency (ANEEL in its Portuguese acronym), which annually publishes Ratifying Resolutions that determine energy rates for residential, commercial and industrial consumers. Such resolutions are published on an individual basis in different months for each of the country's power distributors. The graph in Fig. 1 presents the historical evolution of residential electricity prices in Brazil and in five of its important cities (ANEEL, 2017).

The graph in Fig. 1 shows a rise in average electricity prices in Brazil, with an average increase of 5.52\% per year between 2009 and 2015.

The Brazilian market in fuels and biofuels is regulated by the National Agency of Petroleum, Natural Gas and Biofuels (ANP). Contrary to what occurs in the electricity market where rates are set by ANEEL, ANP has no control over the prices of any fuel, so that each distributor is free to set different prices.

The graph in Fig. 2 presents the historical evolution of gasoline prices in Brazil and in five important cities (ANP, 2017).

The graph in Fig. 2 depicts a rise in gasoline prices in Brazil at an 
Table 1

Prices, taxes and discounts for the economic evaluation of battery electric vehicles purchase.

\begin{tabular}{|c|c|c|c|c|c|c|c|}
\hline City & State & Abbr. & $\begin{array}{l}\text { Electricity price }^{\mathrm{a}} \mathrm{P}_{\text {elec }} \\
\text { [US\$ } \$ / \mathrm{kWh} \text { ] }\end{array}$ & $\begin{array}{l}\text { Gasoline price }{ }^{b} P_{\text {gas }} \\
{[\mathrm{US} \$ / 1]}\end{array}$ & $\begin{array}{l}\text { ICEV annual tax } \\
\mathrm{T}_{\text {ICEV }}[\mathrm{US} \$ / \mathrm{ano}]\end{array}$ & $\begin{array}{l}\text { BEV annual tax }{ }^{\mathrm{d}} \mathrm{T}_{\mathrm{BEV}} \\
\text { [US\$/ano] }\end{array}$ & $\begin{array}{l}\text { Discount on BEV annual tax } \\
\text { payment }^{\mathrm{e}} \mathrm{D}[\%]\end{array}$ \\
\hline Brasília & Distrito Federal & $\mathrm{DF}$ & 17.09 & 1.12 & 661.64 & $1,070.52$ & $0.00 \%$ \\
\hline Goiânia & Goiás & GO & 19.90 & 1.04 & 708.90 & $1,146.99$ & $0.00 \%$ \\
\hline Cuiabá & Mato Grosso & MT & 19.16 & 1.08 & 378.08 & 611.73 & $0.00 \%$ \\
\hline Campo Grande & Mato Grosso do Sul & MS & 17.94 & 0.98 & 661.64 & $1,070.52$ & $50.00 \%$ \\
\hline Maceió & Alagoas & $\mathrm{AL}$ & 18.56 & 0.99 & 756.16 & $1,223.46$ & $0.00 \%$ \\
\hline Salvador & Bahia & BA & 16.48 & 1.05 & 472.60 & 764.66 & $0.00 \%$ \\
\hline Fortaleza & Ceará & $\mathrm{CE}$ & 17.14 & 1.11 & 472.60 & 764.66 & $100.00 \%$ \\
\hline Sào Luís & Maranhão & MA & 16.18 & 0.99 & 472.60 & 764.66 & $100.00 \%$ \\
\hline Joảo Pessoa & Paraíba & $\mathrm{PB}$ & 17.80 & 1.04 & 378.08 & 611.73 & $0.00 \%$ \\
\hline Recife & Pernambuco & $\mathrm{PE}$ & 16.37 & 1.05 & 661.64 & $1,070.52$ & $100.00 \%$ \\
\hline Teresina & Piauí & PI & 18.20 & 1.04 & 472.60 & 764.66 & $100.00 \%$ \\
\hline Natal & $\begin{array}{l}\text { Rio Grande do } \\
\text { Norte }\end{array}$ & $\mathrm{RN}$ & 15.57 & 1.07 & 567.12 & 917.59 & $100.00 \%$ \\
\hline Aracaju & Sergipe & SE & 17.47 & 1.07 & 378.08 & 611.73 & $100.00 \%$ \\
\hline Rio Branco & Acre & $\mathrm{AC}$ & 17.19 & 1.15 & 378.08 & 611.73 & $0.00 \%$ \\
\hline Macapá & Amapá & AP & 10.12 & 1.01 & 567.12 & 917.59 & $0.00 \%$ \\
\hline Manaus & Amazonas & $\mathrm{AM}$ & 18.44 & 1.01 & 567.12 & 917.59 & $0.00 \%$ \\
\hline Belém & Pará & PA & 21.76 & 1.08 & 472.60 & 764.66 & $0.00 \%$ \\
\hline Porto Velho & Rondônia & RO & 18.27 & 1.10 & 567.12 & 917.59 & $0.00 \%$ \\
\hline Boa Vista & Roraima & $\mathrm{RR}$ & 15.09 & 1.10 & 567.12 & 917.59 & $0.00 \%$ \\
\hline Palmas & Tocantins & TO & 18.86 & 1.08 & 378.08 & 611.73 & $0.00 \%$ \\
\hline Vitória & Espírito Santo & ES & 19.30 & 1.03 & 378.08 & 611.73 & $0.00 \%$ \\
\hline Belo Horizonte & Minas Gerais & MG & 22.58 & 1.02 & 756.16 & $1,223.46$ & $0.00 \%$ \\
\hline Rio de Janeiro & Rio de Janeiro & $\mathrm{RJ}$ & 22.50 & 1.10 & 756.16 & $1,223.46$ & $87.50 \%$ \\
\hline Sáo Paulo & São Paulo & SP & 17.85 & 1.00 & 756.16 & $1,223.46$ & $62.50 \%$ \\
\hline Curitiba & Paraná & PR & 22.29 & 1.00 & 661.64 & $1,070.52$ & $0.00 \%$ \\
\hline Porto Alegre & Rio Grande do Sul & RS & 19.92 & 1.13 & 567.12 & 917.59 & $100.00 \%$ \\
\hline Florianópolis & Santa Catarina & SC & 18.40 & 1.00 & 378.08 & 611.73 & $0.00 \%$ \\
\hline
\end{tabular}

a Source: rates for January 2016 (ANEEL, 2017), considering monthly electricity consumption between 351 and $500 \mathrm{~kW}$ h, including federal and state taxes. The exchange rate used in this work is $3.50 \mathrm{R} \$ / \mathrm{US} \$$.

b Source: data from January 2016 (ANP, 2017), including taxes.

c Source: calculated by the author through a Toyota Corolla retail price and the annual tax rate of each studied city.

d Source: calculated by the author through a $30 \mathrm{kWh}$ Nissan Leaf retail price and the annual tax rate of each studied city.

e Source: ABVE (2017), except for the cities of Rio de Janeiro (FAZENDA, 1997) and São Paulo (SEFAZ, 2008; SP, 2014).

Table 2

Data on vehicles and their intensity of use for the economic analysis of battery electric vehicles purchase.

\begin{tabular}{llll}
\hline & Symbol & Value & Unit \\
\hline Annual distance travelled $^{\mathrm{a}}$ & $\mathrm{ADT}$ & 20,000 & $\mathrm{~km}$ \\
Fuel economy of conventional vehicles $^{\mathrm{b}}$ & $\mathrm{FE}_{\mathrm{ICEV}}$ & 13.61 & $\mathrm{~km} / \mathrm{l}$ \\
Fuel economy of electric vehicles $^{\mathrm{c}}$ & $\mathrm{FE}_{\mathrm{BEV}}$ & 5.37 & $\mathrm{~km} / \mathrm{kWh}$ \\
ICEV retail price $^{\mathrm{d}}$ & & $23,630.00$ & $\mathrm{US} \$$ \\
BEV retail price $^{\mathrm{e}}$ & & $38,233.00$ & $\mathrm{US} \$$ \\
Cost of investment $^{\mathrm{f}}$ & $\mathrm{CI}$ & $14,603.00$ & $\mathrm{US \$}$ \\
\hline
\end{tabular}

a Source: Value adopted by the author based on Choma and Ugaya (2015) and Dias et al. (2014).

b Source: Toyota Corolla data (DOE, 2016a).

c Source: $30 \mathrm{~kW}$ h battery Nissan Leaf data (DOE, 2016b).

d Source: Toyota Corolla approximate retail price in Brazil (FIPE, 2016).

e Source: $30 \mathrm{kWh}$ Nissan Leaf approximate retail price in Brazil (estimated by the author).

f Source: Retail price difference between a Toyota Corolla and a $30 \mathrm{kWh}$ Nissan Leaf.

average rate of $4.62 \%$ per year between 2009 and 2015 .

\subsection{Economic analysis}

This subsection discusses the results of the economic analysis of purchasing battery electric vehicles. By using Eq. (6) and the data from Tables 1 and 2, the payback period of purchasing electric vehicles was calculated for all Brazilian state capitals, as shown in Table 3. The table also displays payback values if all capitals granted full exemption from annual tax payment to battery electric vehicles, i.e. a simulation is

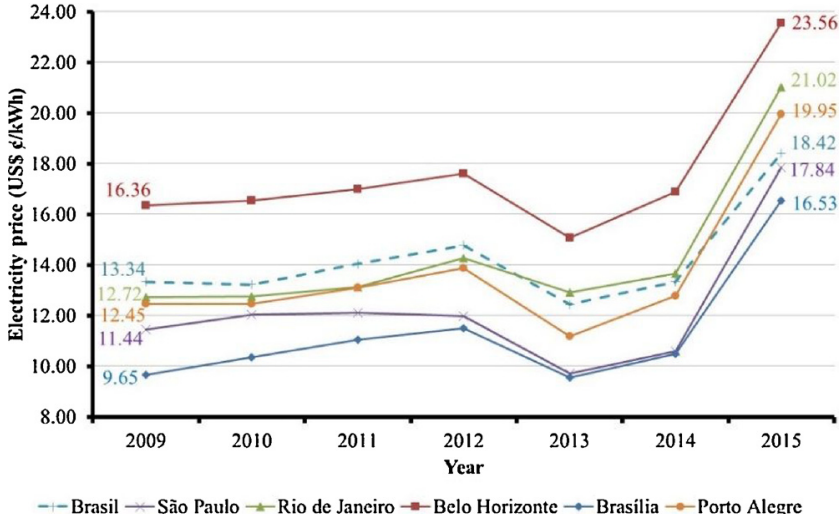

Fig. 1. Historical evolution of residential electricity prices in Brazil and in five selected cities.

carried out which considers the percentage discount of $100 \%$ on the annual tax payment.

By analyzing Table 3, it is observed that, currently, only the cities of Fortaleza (CE), Recife (PE), Natal (RN), and Porto Alegre (RS) offer a payback period of less than 10 years, given that all these cities provide owners of battery electric vehicles with a total exemption from the annual tax payment $(\mathrm{D}=100 \%)$. It is worth emphasizing that, among these cities, Porto Alegre is the only one in which the minimum per capita income of $10 \%$ of wealthiest citizens is over US\$1000.00 (IBGE, 2015, 2010), as shown in Fig. 3. As BEVs command higher prices than average of vehicles sold in Brazil, the level of integration of electric vehicles into each city tends to vary according to consumes' ability to 


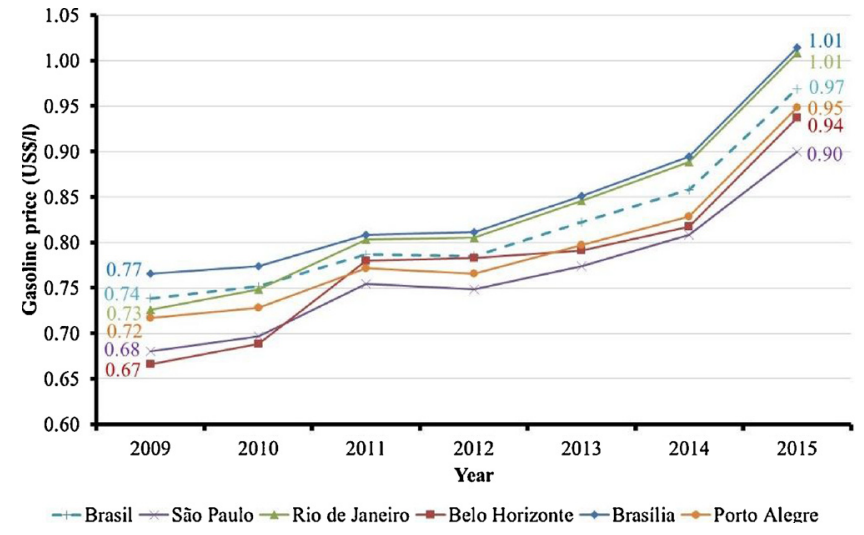

Fig. 2. Historical evolution of gasoline prices in Brazil and in five selected cities.

pay.

In Table 3, there is a difference of $57 \%$ from the arithmetic mean of the actual payback period and the arithmetical mean of the payback value considering total exemption from annual tax payment $(\mathrm{D}=100 \%)$. By evaluating only the cities that currently do not grant discounts on tax payment, the difference reaches $67 \%$.

The graph in Fig. 4 shows the behavior of the percentage variation in the payback period of purchasing a BEV as a function of the percentage variation of gasoline prices in five major cities. On the other hand, the graph in Fig. 5 shows the behavior of the percentage variation in the payback period as a function of the percentage change in electricity prices.

It is noted in graphs of Figs. 4 and 5 that variations in payback period are more influenced by changes in the price of gasoline as compared to the prices of electricity. In addition, it was observed that in

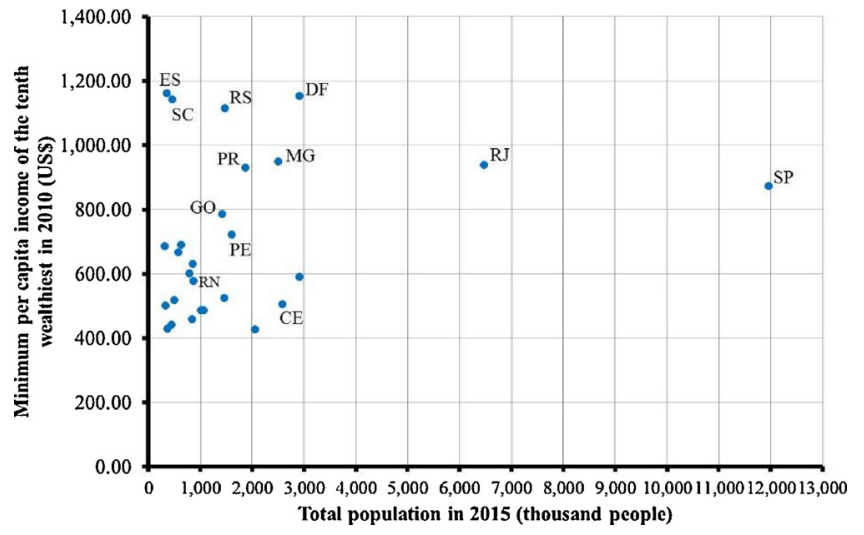

Fig. 3. Population and minimum per capita income of $10 \%$ of the wealthiest citizens of brazilian capitals.

cities where there is no grant of a discount on the annual tax payment (Belo Horizonte and Brasília), variations in the payback period are more sensitive to changes in gasoline and electricity prices since, in these cities, savings with the use of electric vehicles comes solely from the price difference between gasoline and electricity.

The importance of granting a discount on the annual electric vehicle tax payment can be best assessed from Fig. 6, which presents a sensitivity analysis of the percentage variation in payback period for different percentages of discount on the annual tax payment in five key cities. In the cities of Brasilia and Belo Horizonte, where there is no grant of a discount on the annual tax payment $(\mathrm{D}=0 \%)$, there is shown to be great potential for improvement in the payback period, since it could be reduced by up to $64 \%$ and $87 \%$, respectively, while if total exemption from EV annual tax payments were granted in the cities of Brasilia and Belo Horizonte, it would demonstrate that such exemption

Table 3

Payback period of purchasing electric vehicles for brazilian state capitals.

\begin{tabular}{|c|c|c|c|c|c|}
\hline City & State & Abbr. & $\begin{array}{l}\text { Actual payback period } \\
\text { [years] }\end{array}$ & $\begin{array}{l}\text { Payback period including the exemption from annual tax payment } \\
(\mathrm{D}=100 \%) \text { [years] }\end{array}$ & Difference [\%] \\
\hline Brasília & Distrito Federal & DF & 24.35 & 8.74 & $-64 \%$ \\
\hline Goiânia & Goiás & GO & 41.41 & 9.74 & $-76 \%$ \\
\hline Cuiabá & Mato Grosso & MT & 23.00 & 11.71 & $-49 \%$ \\
\hline Campo Grande & Mato Grosso do Sul & MS & 16.27 & 10.19 & $-37 \%$ \\
\hline Maceió & Alagoas & $\mathrm{AL}$ & 48.34 & 9.57 & $-80 \%$ \\
\hline Salvador & Bahia & BA & 22.72 & 10.37 & $-54 \%$ \\
\hline Fortaleza & Ceará & $\mathrm{CE}$ & 9.98 & 9.98 & $0 \%$ \\
\hline Sảo Luís & Maranhão & MA & 11.04 & 11.04 & $0 \%$ \\
\hline Joảo Pessoa & Paraíba & $\mathrm{PB}$ & 22.99 & 11.71 & $-49 \%$ \\
\hline Recife & Pernambuco & $\mathrm{PE}$ & 9.15 & 9.15 & $0 \%$ \\
\hline Teresina & Piauí & PI & 11.01 & 11.01 & $0 \%$ \\
\hline Natal & Rio Grande do Norte & $\mathrm{RN}$ & 9.35 & 9.35 & $0 \%$ \\
\hline Aracaju & Sergipe & SE & 11.29 & 11.29 & $0 \%$ \\
\hline Rio Branco & Acre & AC & 17.77 & 10.19 & $-43 \%$ \\
\hline Macapá & Amapá & AP & 19.25 & 8.71 & $-55 \%$ \\
\hline Manaus & Amazonas & $\mathrm{AM}$ & 32.26 & 10.66 & $-67 \%$ \\
\hline Belém & Pará & $\mathrm{PA}$ & 30.17 & 11.69 & $-61 \%$ \\
\hline Porto Velho & Rondônia & RO & 25.14 & 9.75 & $-61 \%$ \\
\hline Boa Vista & Roraima & $\mathrm{RR}$ & 20.64 & 8.98 & $-56 \%$ \\
\hline Palmas & Tocantins & TO & 22.45 & 11.57 & $-48 \%$ \\
\hline Vitória & Espírito Santo & ES & 26.14 & 12.48 & $-52 \%$ \\
\hline Belo Horizonte & Minas Gerais & MG & 76.88 & 10.33 & $-87 \%$ \\
\hline Rio de Janeiro & Rio de Janeiro & RJ & 10.58 & 9.52 & $-10 \%$ \\
\hline Sào Paulo & São Paulo & SP & 13.31 & 9.38 & $-30 \%$ \\
\hline Curitiba & Paraná & PR & 62.43 & 11.19 & $-82 \%$ \\
\hline Porto Alegre & Rio Grande do Sul & RS & 9.82 & 9.82 & $0 \%$ \\
\hline Florianópolis & Santa Catarina & SC & 26.35 & 12.53 & $-52 \%$ \\
\hline \multicolumn{6}{|c|}{ ARITHMETIC MEAN } \\
\hline \multicolumn{3}{|c|}{ All 27 evaluated cities } & 24.23 & 10.39 & $-57 \%$ \\
\hline \multicolumn{3}{|c|}{7 cities with current discount of $D=100 \%$} & 10.24 & 10.24 & $0 \%$ \\
\hline \multicolumn{3}{|c|}{17 cities with current discount of $\mathrm{D}=0 \%$} & 31.90 & 10.58 & $-67 \%$ \\
\hline
\end{tabular}




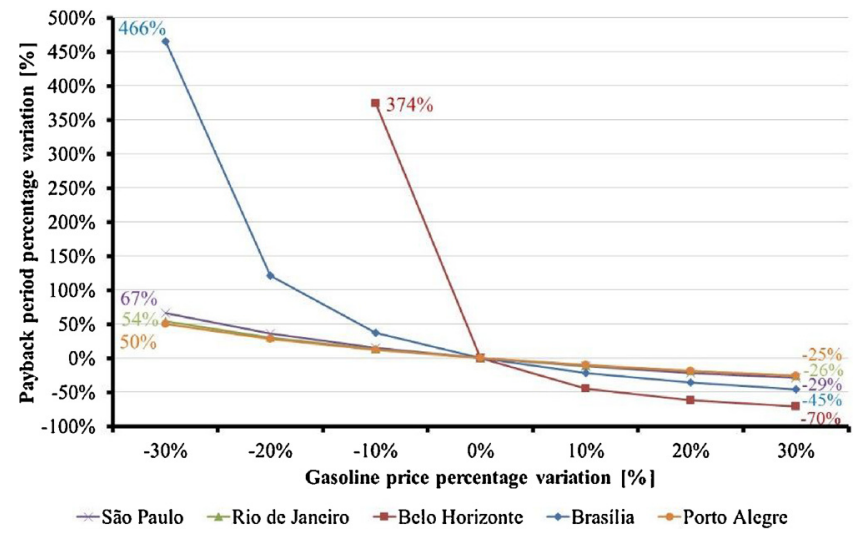

Fig. 4. Percentage variation in payback period of purchasing battery electric vehicles as a function of the percentage variation in gasoline prices in five major cities.

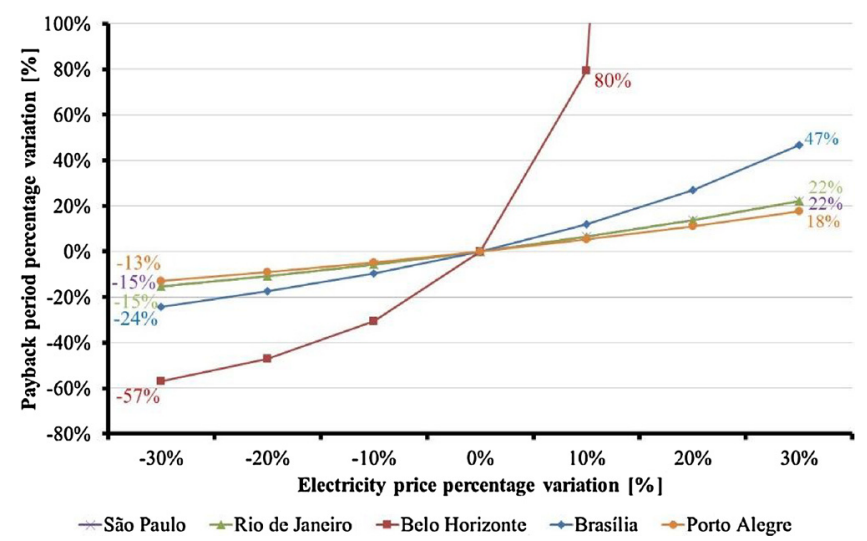

Fig. 5. Percentage variation in payback period of purchasing battery electric vehicles as a function of the percentage variation in electricity prices in five major cities.

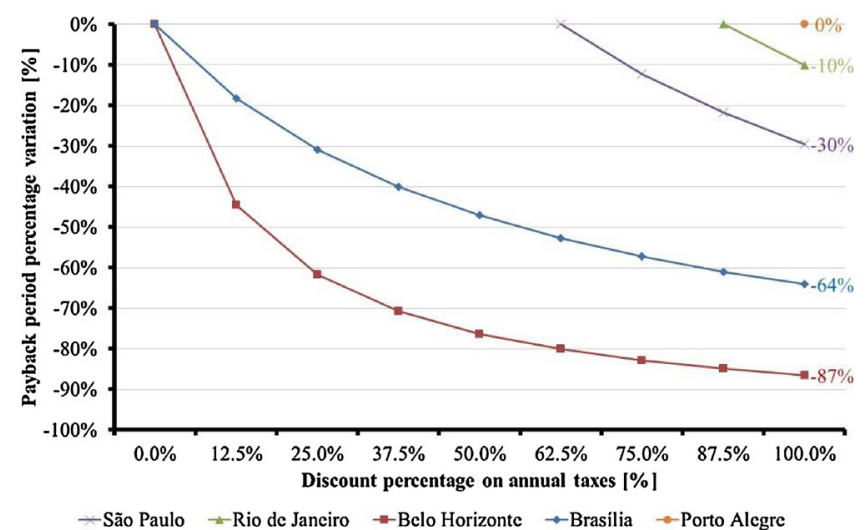

Fig. 6. Percentage variation in payback period of purchasing battery electric vehicles as a function of discount percentage on annual taxes in five selected cities.

is an important policy yet to be analyzed by all Brazilian capitals.

Fig. 6 also shows that, in the cities of São Paulo and Rio de Janeiro, the payback period could be reduced by up to $30 \%$ and $10 \%$, respectively, compared to the current situation which provides a discount on annual tax payment of $62.5 \%$ in São Paulo and $87.5 \%$ in Rio de Janeiro. The city of Porto Alegre has no potential for reducing its payback period, given that it currently grants a $100 \%$ discount on the annual tax payment.

The sensitivity analysis of the percentage variation in payback

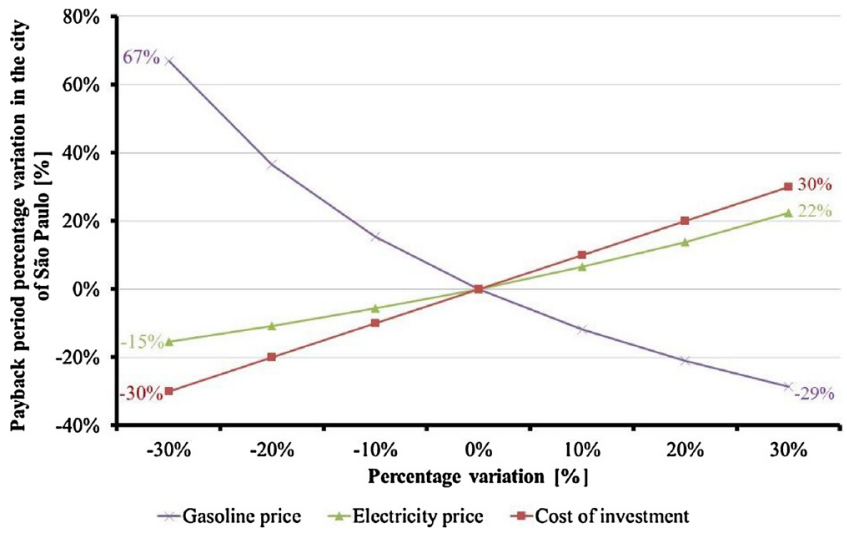

Fig. 7. Percentage variation in payback period of purchasing battery electric vehicles as a function of the percentage variation of prices of gasoline, electricity, and cost of investment in São Paulo.

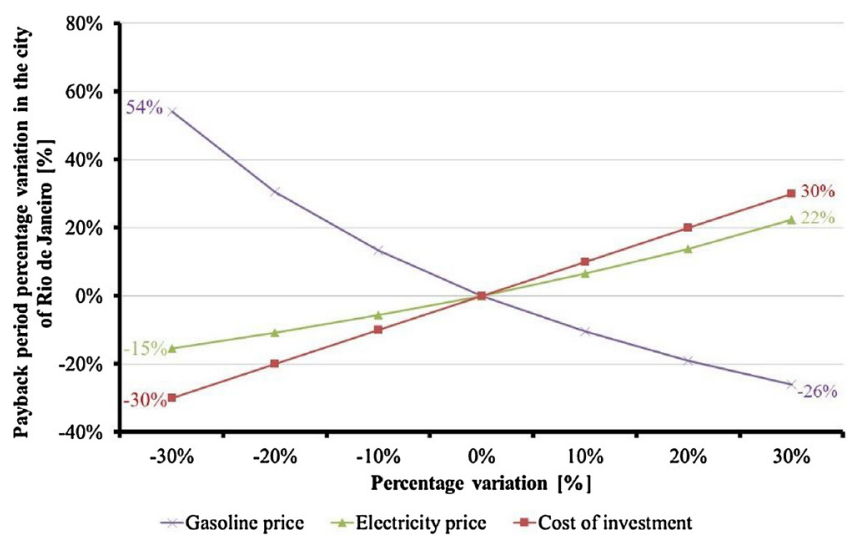

Fig. 8. Percentage variation in payback period of purchasing battery electric vehicles as a function of the percentage variation of prices of gasoline, electricity, and cost of investment in Rio de Janeiro.

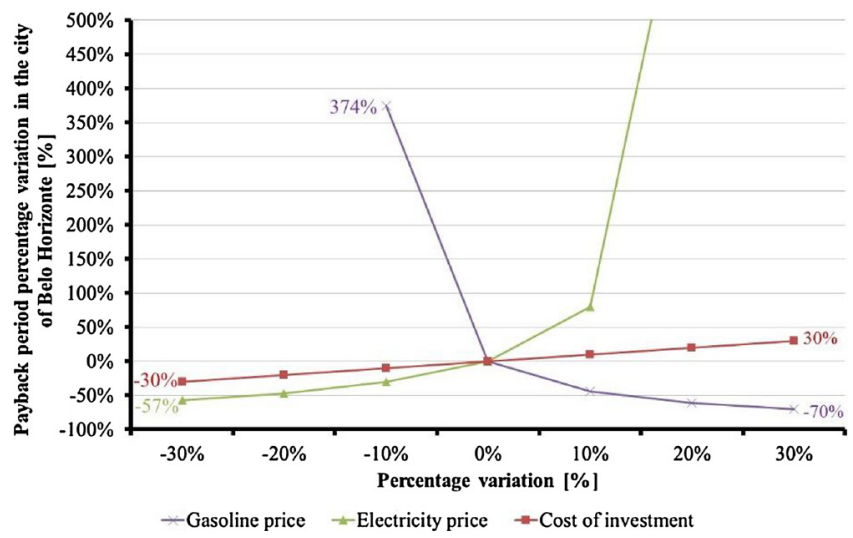

Fig. 9. Percentage variation in payback period of purchasing battery electric vehicles as a function of the percentage variation of prices of gasoline, electricity, and cost of investment in Belo Horizonte.

period for different percentage variation in prices of gasoline, electricity, and cost of the investment in the cities of São Paulo, Rio de Janeiro, Belo Horizonte, Brasilia, and Porto Alegre are shown in Figs. 7-11, respectively.

In Figs. $7-11$, it is observed that the payback period percentage variation as a function of investment cost percentage variation is linear, i.e. for each $1 \%$ variation in investment cost there is a $1 \%$ variation in the payback period. It is also noted that the variable that most sensitively affects payback period is gasoline price. 


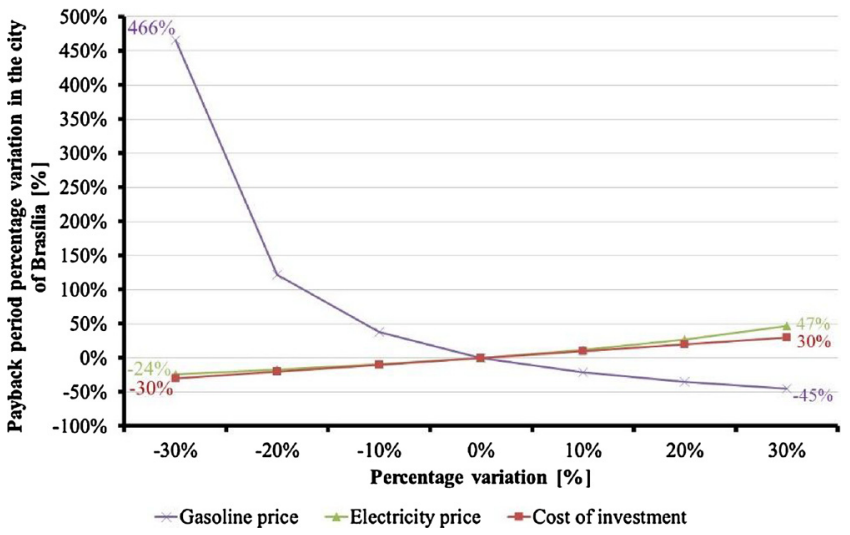

Fig. 10. Percentage variation in payback period of purchasing battery electric vehicles as a function of the percentage variation of prices of gasoline, electricity, and cost of investment in Brasília.

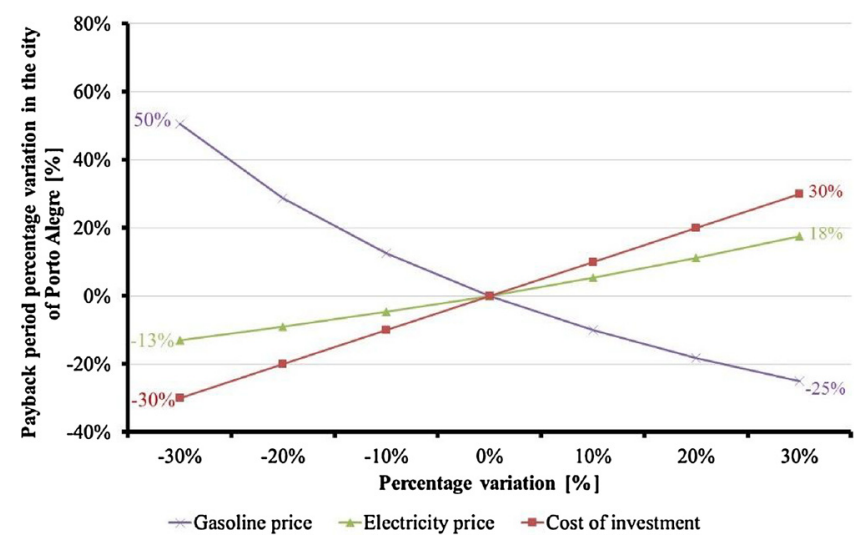

Fig. 11. Percentage variation in payback period of purchasing battery electric vehicles as a function of the percentage variation of prices of gasoline, electricity, and cost of investment in Porto Alegre.

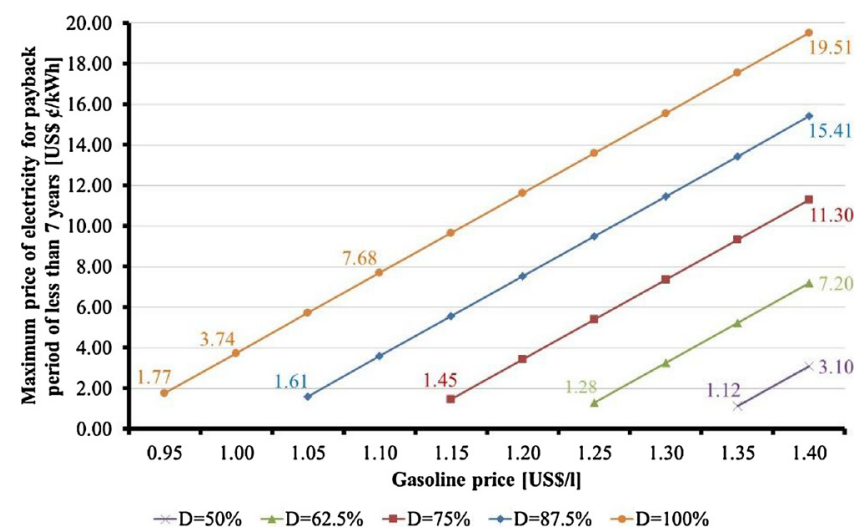

Fig. 12. Maximum price of electricity for payback period of less than 7 years as a function of gasoline price for different percentages of discount on annual tax payment in São Paulo, Rio de Janeiro and Belo Horizonte.

For decision-makers and others involved in the process of BEV integration in Brazil, it is interesting to have a graph that shows the maximum electricity price $\left(\mathrm{P}_{\text {elec }}\right)$ as a function of the price of gasoline $\left(\mathrm{P}_{\text {gas }}\right)$ for different percentages values of the discount on the annual tax payment (D) so that the payback period is lower than a given value. Thus, Fig. 12 shows the electricity price range in São Paulo, Rio de Janeiro and Belo Horizonte that maintain a payback period of less than seven years (value taken as reference in this work) as a function of different gasoline prices; it takes into account different percentage discounts on the annual tax payment.

In Fig. 12, it is noted that, even by considering a $100 \%$ discount on the annual tax payment and the price of gasoline ranging from US\$ 1.00 to US\$1.10/1, which covers the gasoline price range in São Paulo, Rio de Janeiro, and Belo Horizonte, the maximum electricity price should vary between US\$ 3.74 and US $\$ 7.68 \mathrm{\$} / \mathrm{kWh}$ to obtain a payback period of less than seven years. However, the existing electricity prices in these three cities range from US\$ 17.85 to US\$ 22.58 \$/kWh (see Table 1) higher than the maximum price range shown in Fig. 12.

\section{Conclusions and policy implications}

In conclusion, the purchase of battery electric vehicles in Brazil currently is not economically viable, given that the arithmetic mean of the payback period of purchasing such vehicles in the 27 evaluated capitals is 24.23 years, with Recife offering the lowest payback period, 9.15 years.

The factors that most influence the change in payback period throughout Brazilian cities are the price of gasoline and the discount percentage granted on annual electric vehicle tax payments, since only seven capital cities grant a $100 \%$ exemption from the annual tax payment, meaning there is still quite a bit of room for policies to be deployed with the purpose of increasing the number of cities that grant an exemption from the electric vehicles annual tax payment. It was verified that such an exemption could reduce the payback period of cities that do not currently grant discounts on tax payments by about $67 \%$, most markedly Belo Horizonte, where there might be a reduction of up to $87 \%$. Even were the $100 \%$ discount to be granted on the annual tax payment in all the analyzed cities, the arithmetic mean of the payback period would still be 10.39 years.

It was found that there is a linear relationship between the variations in payback period and investment cost for purchasing electric vehicles, in such a way that each $1 \%$ reduction in the cost of investment represents a $1 \%$ reduction in payback period.

By considering a $100 \%$ discount on the annual tax payment and the current gasoline prices in São Paulo, Rio de Janeiro, and Belo Horizonte, only low prices of electricity ranging from US\$ 3.74 \$ to US\$ $7.68 \mathrm{\phi} / \mathrm{kWh}$ would result in payback periods of less than seven years.

Only a set of integrated policies that include full exemption from the annual tax payment, a reduction in the investment cost and in the price of electricity for electric vehicle owners can accelerate the integration of such vehicles in Brazilian cities. So it seems there is considerable distance that will have to be traveled before the adoption curve spikes upward.

\section{Acknowledgements}

This research did not receive any specific grant from funding agencies in the public, commercial, or not-for-profit sectors.

\section{References}

ABVE, 2017. Imposto sobre a Propriedade de Veículos Automotores para veículos elétricos. . (Accessed June 2017). http://www.abve.org.br/diversos/15/legislacao. ANEEL, 2017. Biblioteca Virtual da Agência Nacional de Energia Elétrica: Resoluções homologatórias com a publicação das tarifas de energia elétrica de cada distribuidora de energia. . (Accessed July 2017). http://biblioteca.aneel.gov.br/index.html. ANFAVEA, 2016. Brazilian Automotive Industry Yearbook 2016. Sao Paulo, Brazil, 150 pp.

ANP, 2017. Defesa da Concorrência e Preços: Série histórica do Levantamento de Preços e de Margens de Comercialização de Combustíveis. . (Accessed July 2017). http:// www.anp.gov.br/?id $=2368$.

Baran, R., Legey, L.F.L., 2013. The introduction of electric vehicles in Brazil: impacts on oil and electricity consumption. Technol. Forecast. Soc. Change 80 (5), 907-917.

Bonges III, H.A., Lusk, A.C., 2016. Addressing electric vehicle (EV) sales and range anxiety through parking layout, policy and regulation. Transp. Res. Part A 83, 63-73.

Choma, E.F., Ugaya, C.M.L., 2015. Environmental impact assessment of increasing electric vehicles in the Brazilian fleet. J. Clean. Prod. 152, 497-507.

Dias, M.V.X., et al., 2014. The impact on electricity demand and emissions due to the introduction of electric cars in the São Paulo power system. Energy Policy 65, 
298-304.

DOE, 2016a. Fuel economy information: Toyota Corolla. . (Accessed June 2016). http:// www.fueleconomy.gov/feg/Find.do? action $=$ sbs\&id $=36801$.

DOE, 2016b. Fuel economy information: Nissan Leaf $30 \mathrm{kWh}$. . (Accessed June 2016). http://www.fueleconomy.gov/feg/Find.do?action $=$ sbs\&id $=37067$.

FAZENDA, 1997. Lei n.ำ 2877 de 1997. Secretaria de Estado de Fazenda do Rio de Janeiro, Rio de Janeiro, Brazil.

FIPE, 2016. Preço médio de veículos no Brasil: junho de 2016. . (Accessed June 2016). http://veiculos.fipe.org.br.

IBGE, 2010. Censo demográfico 2010. Instituto Brasileiro de Geografia e Estatística, Rio de Janeiro, Brazil.

IBGE, 2015. Instituto Brasileiro de Geografia e Estatística: Estimativas de população para $1^{\circ}$ de julho de 2015. . (Accessed June 2016). http://www.ibge.gov.br/home/ estatistica/populacao/estimativa2015/estimativa_tcu.shtm.

ICCT, 2015. Transition to a Global Zero-emission Vehicle Fleet: a Collaborative Agenda for Governments. Washington DC, United States, 40 pp. .

IPCC, 2014. Climate Change 2014: Synthesis Report. Contribution of Working Groups I, II and III to the Fifth Assessment Report of the Intergovernmental Panel on Climate Change. IPCC, Geneva, Switzerland 151 pp.

MCTI, 2014. Estimativas anuais de emissões de gases de efeito estufa no Brasil: $2^{\mathrm{a}}$ Edição. Brasilia, Brazil, 161 pp. .

Noori, M., et al., 2015. Electric vehicle cost, emissions, and water footprint in the United States: development of a regional optimization model. Energy 89, 610-625.

Rusich, A., Danielis, R., 2015. Total cost of ownership, social lifecycle cost and energy consumption of various automotive technologies in Italy. Res. Transp. Econ. 50, $3-16$.
SEFAZ, 2008. Lei n. ${ }^{\circ} 13296$ de 2008. Secretaria da Fazenda, São Paulo, Brazil.

Silvia, C., Krause, R.M., 2016. Assessing the impact of policy interventions on the adoption of plug-in electric vehicles: an agent-based model. Energy Policy 96, $105-118$.

SP, 2014. Lei n.ํำ 15997 de 2014. Prefeitura de São Paulo, São Paulo, Brazil.

Ricardo Emilio da Silva is an electrical engineer at the Brazilian National Institute for Space Research (INPE) and a Ph.D. student in Energy Transmission and Conversion area at Sao Paulo State University (UNESP) in Guaratingueta, Brazil. He holds a B.S. in Electrical Engineering and an M.S. in Mechanical Engineering from Sao Paulo State University (UNESP) in Guaratingueta, Brazil.

Pedro Magalhaes Sobrinho is a Professor in the Department of Energy at Sao Paulo State University (UNESP) in Guaratingueta, Brazil. He holds a B.S. in Mechanical Engineering from the University of Taubaté (UNITAU), Brazil, as well as M.S. and Ph.D. degrees in Mechanical Engineering from Sao Paulo State University (UNESP) in Guaratingueta, Brazil.

Teófilo Miguel de Souza is a Professor with the Department of Electrical engineering at Sao Paulo State University (UNESP) in Guaratingueta, Brazil. He holds undergraduate degrees in Electrical Engineering from the Federal University of Juiz de Fora (UFJF) and Aeronautical Engineering from the University of Taubate (UNITAU), Brazil, as well as M.S. and Ph.D. degrees in Materials Engineering from the University of Sao Paulo (USP) in Lorena, Brazil. 